\title{
Revitalization of historic railway bridges on the example of a structure in Łęknica (Poland)
}

\author{
Artur Juszczyk ${ }^{1, *}$ \\ ${ }^{1}$ University of Zielona Góra, Faculty of Building, Architecture and Environmental, Poland
}

\begin{abstract}
In the article, an attempt is made to describe the scale of the problem of the revitalization of railway bridges found on lines no longer in use. The issue of changes in use of historic railway bridges is considered on the example of a bridge in Łęknica built in the years 1897-1898. The described bridge is untypical due to the inverted parabolic truss girders and the placement of 9 spans in a horizontal arch of a small radius. The structural solutions of the railway structure as well as the scope of construction works carried out in an effort to adapt it for pedestrian and cyclist traffic have been presented.
\end{abstract}

\section{1 introduction}

Economic development imposes advancements in technology. This would not be possible without transformations of the transportation infrastructure in order to ensure adequate comfort in the transport of people and goods. The second half of the $19^{\text {th }}$ century was the golden period of railways and the infrastructure connected with it. As an effect of these actions, a network of railway lines of great density was created in many regions. Near the end of the $80 \mathrm{~s}$ of the last century, many of these lines within Poland were gradually abandoned, with the existing bridges and overpasses connected with them were left to the uncontrolled effects of time. This was caused by the high costs of maintaining railway traffic and the increased significance of road transport.

The closing down of railway lines is a process spread out over time, with the total of all phases lasting from a few to a few dozen years. It begins with the suspension of passenger railway traffic, and finishes with taking apart the surface and handing the land over to local governments. Efforts should be made to connect decisions regarding the closing down of railway lines with attempts aimed at their revitalization. Coordinating these activities in the scope of changes in their use can bring about vast social and economic benefits. Recovering space and giving it a new meaning has a positive influence on the microregion, which in turn influences neighbouring ones. Carrying out earthworks relying solely on adapting the structure to the new function will enable the expenditure to be to be minimized, as compared to taking apart the structure and constructing a new one. In urbanized areas, the replacement of an abandoned railway line with a new road connection can be observed, an example of which is Zbigniew Hubert St. in Zielona Góra. In the case of the revitalization of engineering structures, it is mainly infrastructure for pedestrian-cyclist traffic that arises.

* Corresponding author: a.juszczyk@ib.uz.zgora.pl (ORCID: 0000-0002-3687-5429) 


\section{Revitalization of historical railway bridges}

Currently, the main manager of rail infrastructure in Poland is PKP Polskie Linie Kolejowe S.A. (Polish Railway Lines). The company is responsible, as of the end of 2008, for the technical state of a large amount of property listed in Table 1. Over half of these objects have been in service for 100 years or more [1], which requires significant investments when adapting the infrastructure to the current legal requirements [2].

Table 1. Railway engineering structures in Poland (on the basis of [1]).

\begin{tabular}{|c|c|c|c|c|}
\hline \multicolumn{2}{|c|}{ Type of structure } & Number & $\begin{array}{l}\text { Total } \\
\text { length }\end{array}$ & $\begin{array}{l}\text { Average } \\
\text { length }\end{array}$ \\
\hline \multirow{8}{*}{$\begin{array}{c}\text { Structures in } \\
\text { use }\end{array}$} & bridge & 3639 & 137703 & 38 \\
\hline & viaduct & 3264 & 87013 & 27 \\
\hline & tunnel & 25 & 20614 & 825 \\
\hline & pedestrian tunnel & 178 & 17579 & 99 \\
\hline & footbridge & 396 & 13285 & 34 \\
\hline & retaining structure & 792 & 123416 & 156 \\
\hline & culvert & 20848 & 397140 & 19 \\
\hline & Total & 25675 & 736007 & 29 \\
\hline \multicolumn{2}{|c|}{ Structures not in service } & 3467 & 60745 & 18 \\
\hline
\end{tabular}

Railway lines which have neither economic nor tourism importance are closed down for economic reasons. According to data presented in Table 1, it can be calculated that engineering structures on closed down railway lines comprise over $10 \%$ of the total, and that their average length is $18 \mathrm{~m}$. Historically, bridge structures are characterized by wide structural variety. Cantilever bridges or truss girders with riveted connections have not been created for many years; they are a reflection of the history of the development of technology and, with time, will vanish from the landscape. This is infrastructure which, without due surveillance, is subject to theft, which further accelerates its degradation.

Railway bridge structures are designed to withstand particularly high operational loads, higher than road structures and not comparable to loads caused by pedestrian or cyclist traffic. In terms of load-bearing capacity, it is not necessary to carry out reinforcement of the structure, while construction works can be limited to securing the structures, which facilitates their revitalization. A problem is ensuring adequate structure clearance, thus a changeover to a pedestrian/cycling path is the most frequently planned solution, which requires the adaptation of the structure of the bridge deck and equipping it. The next characteristic making these types of activities easier is the longitudinal slope, the value of which does not usually exceed one percent. This makes it possible to obtain very good traffic conditions for cyclists while limiting earthwork to a minimum.

Revitalization of abandoned railway lines is a phenomenon raising a lot of interest in Poland over the last years, and selected examples have been described in literature [e.g. 3-5]. Included in such efforts is the Stary Raduszec - Łęknica - Bad Muskau - Weißwasser railway line, which the railway bridge on The Nysa Łużycka River comprises a fragment of. The structure is found on the Polish-German border in Lubuskie Province and Saxony. Thanks to 
the international efforts of local governments, using outside financial resources for transborder purposes, it was possible to impede the progressing degradation and carry out the revitalization of the Tuplice - Łęknica - Bad Muskau part.

\section{Railway bridge in Łęknica}

\subsection{History of the structure}

The bridge over the Łysa Łużycka River, on a section of railway line No. 365 (Stary Raduszec - Bad Muskau) was built in the years 1897-1898 and used until the end of World War II. During the war, in February 1945, it was blown up by the German Army. The pillars and part of the steel spans of the bridge were destroyed, as seen in Figure 1. Upon drawing the PolishGerman border along the Nysa River, it became a border bridge - with Poland responsible for the maintenance of its technical state according to an international agreement. In the years 1954-1955, the structure was rebuilt, though for the next half a century, the decision to open an international train connection was not made. It became a strategic bridge in military terms, as a result of which it was covered by ongoing technical supervision. In the 70 s of the past century, its function was already purely fictitious, as the railway line on the German side had been closed down.

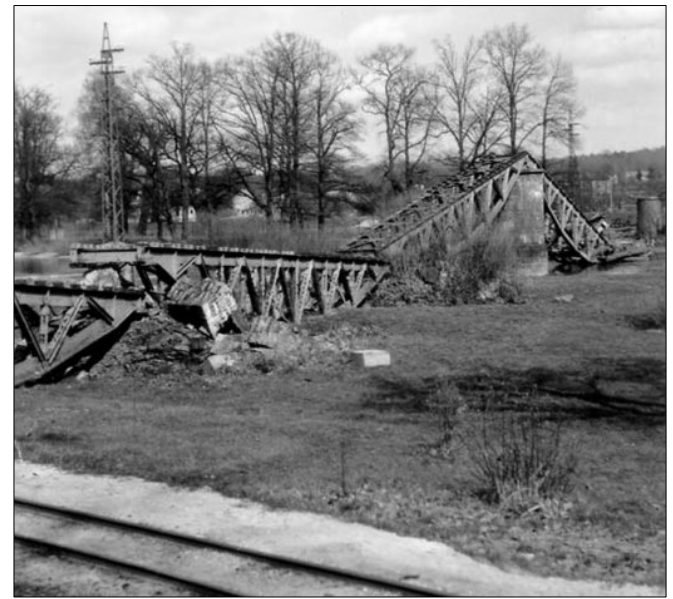

Fig. 1. View of destroyed bridge spans in 1945 [6].

\subsection{Bridge structure and its technical state}

The railway border bridge in Łęknica is a structure made up of 9 freely supported spans. The first span on the western side is a plate girder, while the rest are twin truss girders of an inverted parabolic shape with an unslung truss. All of the connections between structural elements were prepared as riveted connections. The theoretical spread of the spans in the east-west direction is $2 \times 21.45+20.70+4 \times 21.45+21.00+10.90 \mathrm{~m}$, while the length of the entire structure is $186.4 \mathrm{~m}$.

The structure of the bridge is untypical for two reasons. The first is constructing spans with truss girders with an unslung truss over the obstacle in the form of a river. At its normal level, the width of the water flowing in the region of the bridge does not exceed $30 \mathrm{~m}$. The Nysa Łużycka River is an important tributary of the Oder River, collecting water from the western part of the Sudeten Mountains. In the last century, alarm or even flood states have 
been registered on it multiple times, with water flowing beneath each of the nine spans. Another distinguishing feature of the bridge is the fact that it is situated in a horizontal span with a radius of $400 \mathrm{~m}$, which imposed speed limitations of $30 \mathrm{~km} / \mathrm{h}$ on trains.

The technical state of the bridge prior to reconstruction can be assessed as adequate. All rivets in the connections of the truss girders as well as structural elements were complete. The steel spans were severely corroded. Wooden elements of the surface were incomplete and decayed. The bridgeheads were built form solid brick, whereas the intermediate supports of the bridge were made of concrete; moreover, the lower parts of the pillars were cladded with stone blocks. The main damage to the supports is cracking and efflorescence on reinforced concrete elements, as well as missing mortar in the joints of the brick wall. Taking into account the age of the structure as well as its manner of use, it was characterized by typical damage described in literature [7]. Examples of the damage are shown in Fig. 2.
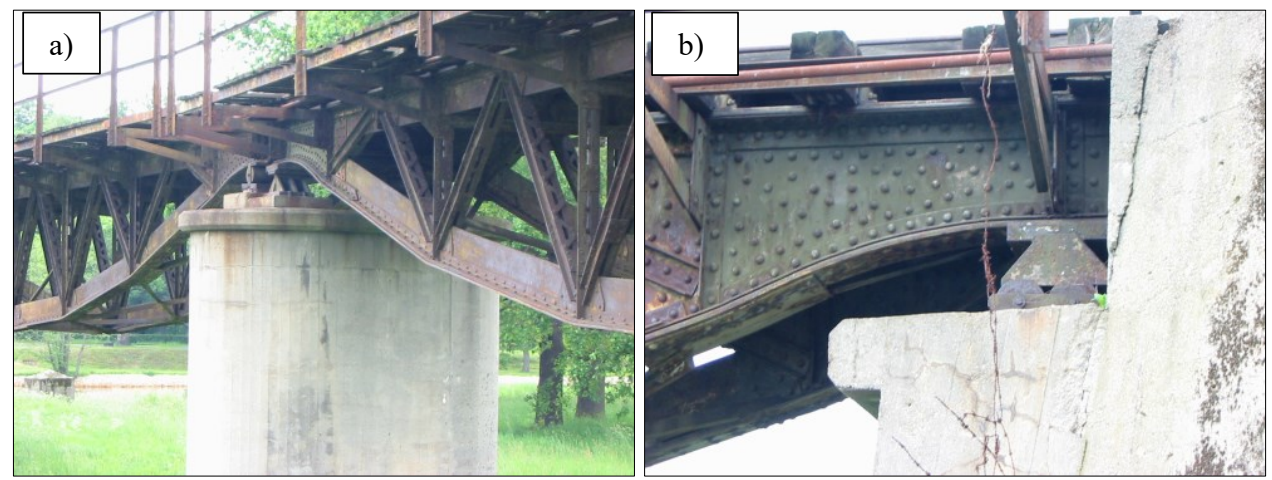

Fig. 2. Corrosion of elements of the Łęknica steel bridge prior to revitalization, a - in the region of a pillar, $\mathrm{b}-$ in the region of a bridgehead (photos by A. Juszczyk).

\subsection{Revitalization of the railway bridge}

The region of Łęknica and Bad Muskau is very interesting as far as tourism is concerned. The best-known attraction is a classical landscape park, set up in the first half of the $19^{\text {th }}$ century by Prince Herman von Pückler-Muskau. The Muzakowski Park, found on both sides of the border, was added to the UNESCO World Heritage List in 2004. The second exceptional object is the Łuk Mużakowa Geopark, which covers very interesting features of the post-mining landscape. Since the beginning of the $19^{\text {th }}$ century to the $70 \mathrm{~s}$ of the past century, shallow-lying deposits of brown coal, ceramic clay and arenaceous quartz, used in the past in the energy sector and ceramic and glass industry, were mined there. The two above-mentioned attractions were the main economic and tourism-related reasons for the construction of a railway line in the region, and currently ratify the development of tourism infrastructure.

Eighteen years passed from the suspension of passenger railway traffic on the Lubsko Łęknica railway line until the commencement of its new use [8]. The railway manager tried to pass the line over to local government in 2004, but in those years, the idea of expanding cycling infrastructure was not a realistic thought. In 2012, a functional-utility Programme commissioned by Żarski Poviat was developed [9], on the basis of which a contractor was selected for design and construction works by tender procedure.

The railway bridge had an open deck with technical space on both sides, and it was thus necessary to prepare a new deck structure. The notion of revitalization called for preserving the historic geometry of the bridge, both in terms of its location on the plan as well as the 
horizontal dimensions of the bridge. The dimensions of the horizontal cross-section of the railway bridge as well as the pedestrian-cyclist bridge are shown in Fig. 3.

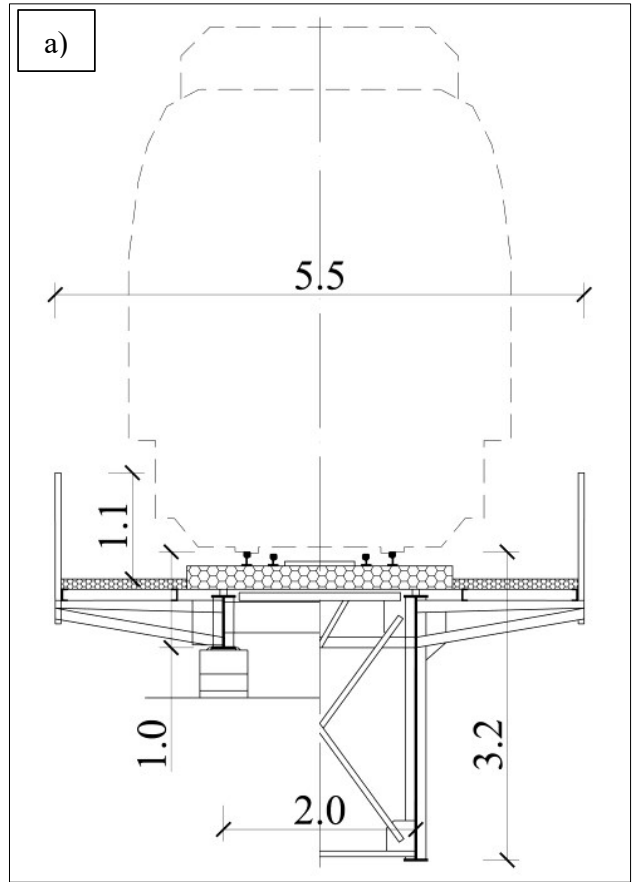

\section{b)}

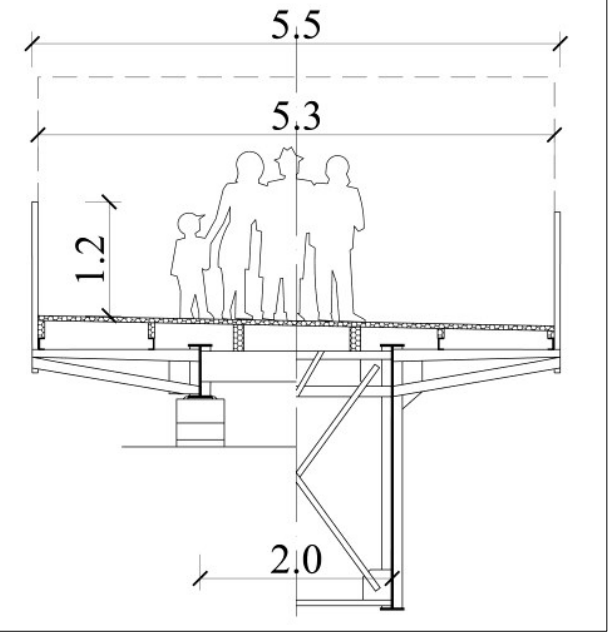

Fig. 3. Horizontal cross section of the bridge in Łęknica, a - for railway traffic, b - for pedestriancyclist traffic (own study).

Construction works in the framework of revitalization covered:

- taking apart the railway surface and elements of the deck,

- the cleaning of the steel structure,

- the anti-corrosion protection of steel elements by applying paint coats,

- building a wooden deck,

- installing road lighting,

- preparing the surface of the pedestrian-cycle path on access ways to the bridge.

Applying wood in the construction of the deck and surface allowed for shortening the realization time and ease of maintaining the curvilinear course of the entire structure. Ventilation spaces were left, which in connection with impregnating agents will extend the durability of the deck. Moreover, it was not necessary to install dilatation devices over each support.

At the stage of preparing the revitalization of the bridge, it is essential to carry out an analysis of the designed structures of the bridge deck. For example, preparing a concrete slab, while maintaining proper drainage, will enable the durability to be increased manifold. In this case, thin surfaces from resins dyed any given colour can also be applied, which additional increases the comfort of use and safety. It should be kept in mind, however, that such a solution will extend the execution time and increase the costs of construction. It is essential to carry out life cycle analysis [10] of the structure accounting for the schedule of expenditures of financial resources and their sources. Revitalization works are largely realized from external resources, but the later maintenance falls on the bridge administrator. This fact is worth remembering when making a decision regarding the choice of technology.

The execution of construction works is present on the sample photographs below (Fig. 4). 

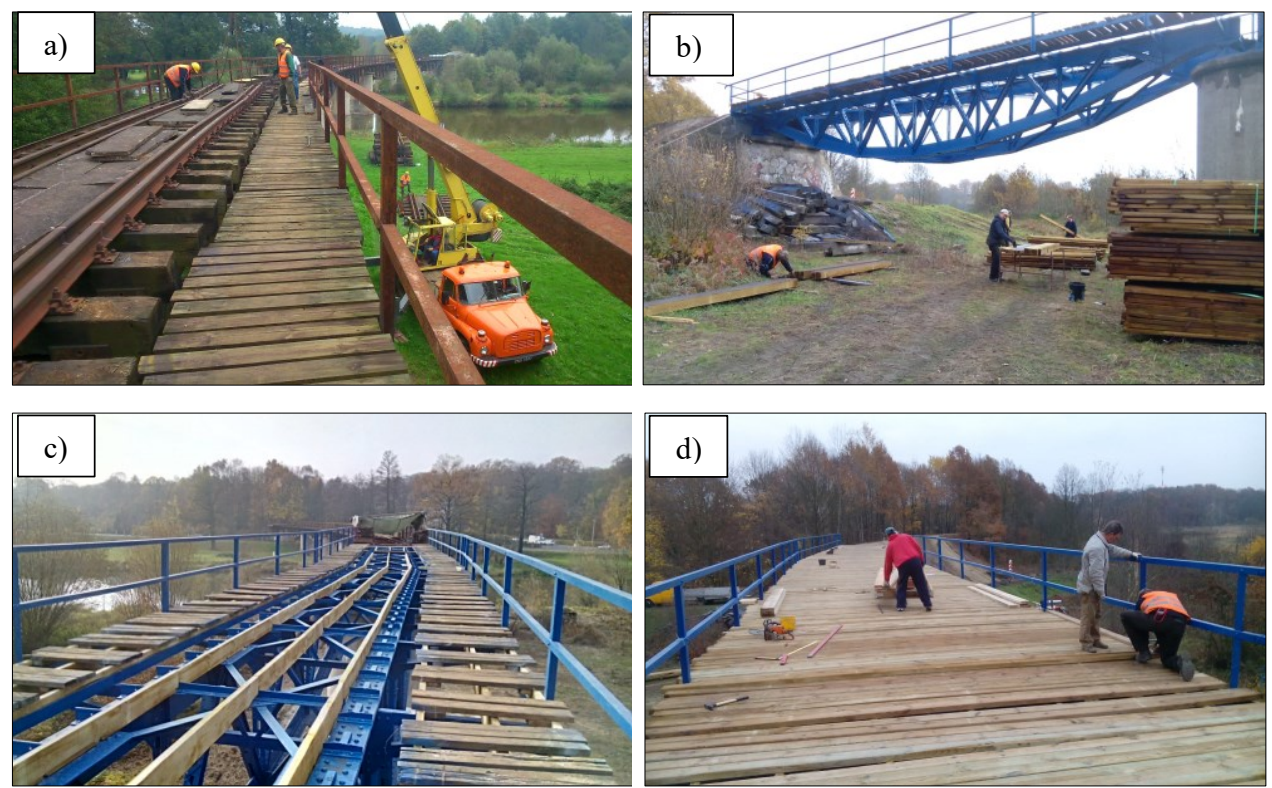

Fig. 4. Selected stages of the revitalization of the bridge in Łęknica, a - taking apart the railway surface, b-d - building the wooden deck, (photos by R. Woźniak).

Elements imitating a railway surface in the form of steel flat bars as well as dark-coloured wood preservatives were introduced in an effort to highlight the original function of the bridge. A view of the surface of the structure is shown in Fig. 5.
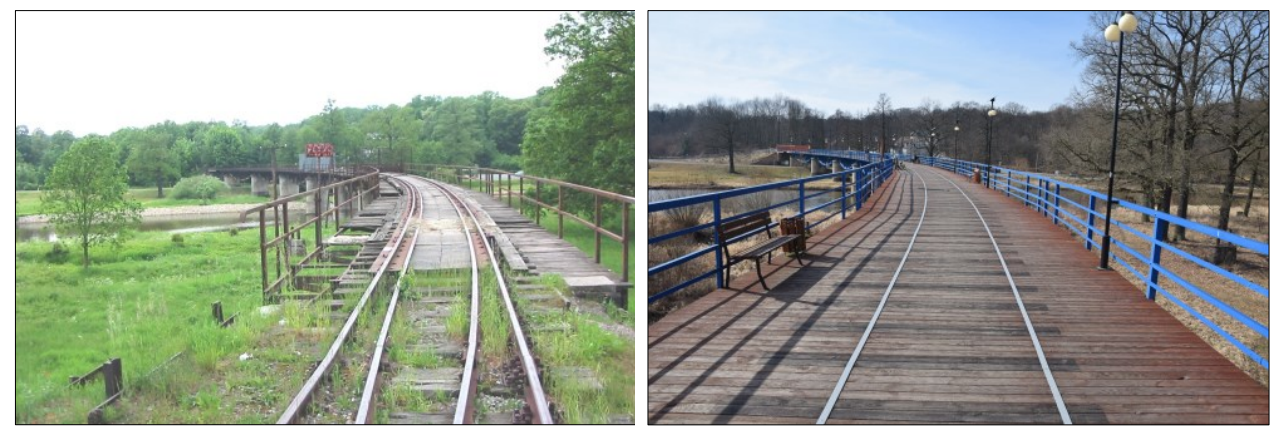

Fig. 5. General view of the railway bridge and pedestrian-cyclist bridge (photos by A. Juszczyk).

The applied paint coats will ensure the protection of the steel structure against corrosion during subsequent years of operation. The view of the span prior to and after the revitalization is shown in Fig. 6. The colour of the steel structure and railings reflect those of railway structures. 

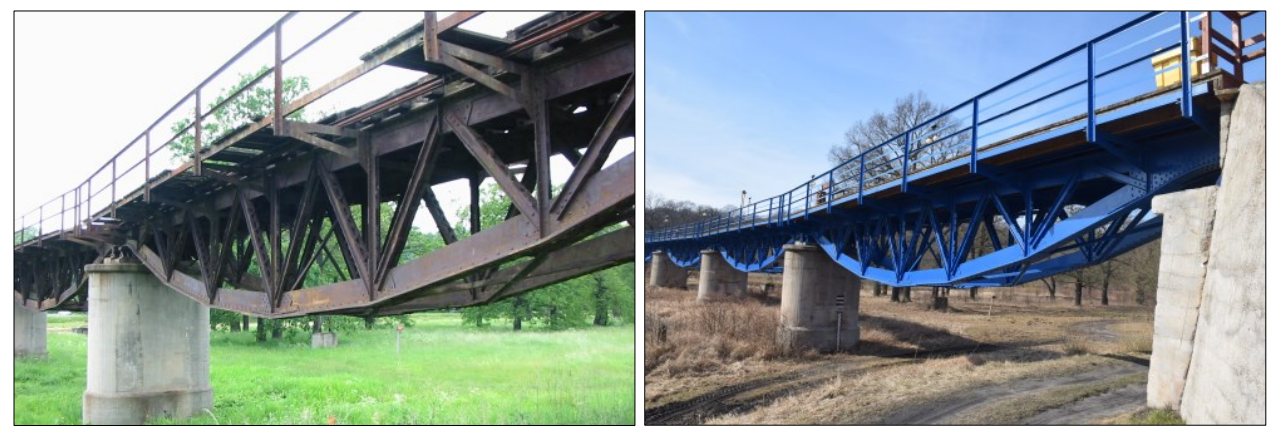

Fig. 6. Peripheral western span prior to and following revitalization (photos by A. Juszczyk).

\section{Summary}

Bridges are an important element of the transportation system, eliminating the restrictions connected with crossing terrain obstacles. Currently, on the Polish-German border section of the Nysa Łużycka River, with a length of just under $198 \mathrm{~km}, 11$ railway bridges (including 3 structures on railway lines enabling train crossings in only the neighbouring countries), 17 roadway bridges and 11 bridges for foot-traffic and cyclists. Many structures were destroyed during military actions and, for over half a century, were not rebuilt. In order to improve the conditions for the integration of cross-border regions, additional structures of this kind are needed.

Currently, a significant part of old bridges are being replaced with new ones. Historic structures with a wide structural variety, which are a reflection of the history of technological development, are slowly disappearing from the landscape. This phenomenon can often be prevented by preparing appropriate plans for their new uses. The possibility of obtaining significant outside resources positively influences revitalization efforts, as well as renovation works. In the first years following World War II, in the framework of rebuilding transportation routes, a common practice in Poland was the relocation of bridge spans. This was caused by the massive demand for along with limited access to construction materials. Nowadays, technically-speaking, this is much easier, though the occurring legal problems and lack of coordination are to be blamed for such projects not being realized in practice.

Ceasing to carry out technical activities connected with the maintenance of structures, including bridges, leads to their quickly progressing degradation, the main reasons behind which are corrosion and the increasingly occurring problem of vandalism. These factors contribute to the costs of revitalization rising manifold, or to simply resorting to securing these structures so that they do not pose a risk resulting from the possibility of the occurrence of a construction disaster. The use of these structures, if only for tourism-related or recreational purposes, makes it possible to save them for future generations. The described revitalization of the railway bridge provides an example of successful actions that are worthy of imitation. We ought to remember, however, that infrastructure is to be created in a sustainable manner, connecting different means of transport. 


\section{References}

1. K. Szadkowski, Technika Transportu Szynowego, 10, pp. 58-66 (2009) [in Polish]

2. Rozporządzenie Ministra Transportu i Gospodarki Morskiej z dnia 10 września 1998 r. w sprawie warunków technicznych, jakim powinny odpowiadać budowle kolejowe i ich usytuowanie (Dz.U. 1998 nr 151 poz. 987 z późniejszymi zmianami) [in Polish]

3. K. Żółtowski, M. Szafrański, Roads and Bridges - Drogi i Mosty, 4(4), pp. 73-85 (2005) [in Polish]

4. B. Rymsza, Czasopismo Techniczne Budownictwo, 19, pp. 277-287 (2011) [in Polish]

5. J. Biliszczuk, R. Dżugaj, H. Onysyk, J. Onysyk, M. Pustelnik, P. Woźny, Mosty, 6, pp. 53-55 (2014) [in Polish]

6. H. Schmidt. Muskauer Anzeiger 299, pp. 7-11 (2015)

7. J. Bień, Uszkodzenia i diagnostyka obiektów mostowych (WKŁ, Warszawa, 2010) [in Polish]

8. [Online] Available: https:// www.bazakolejowa.pl/. [Accessed: 14-Dec-2018]

9. W. Górzny, Cz. Woźniak, Program funkcjonalno-użytkowy budowy traktu pieszorowerowego oraz szlaku kolejowo-górniczego Bad Muskau - Lęknica - Trzebiel Tuplice - Brody w ramach projektu Przygoda z Nysa - zagospodarowanie turystyczne pogranicza polsko-niemieckiego (Biuro Projektowo - Usługowe Wojciech Górzny, Międzyrzecz, 2012) [in Polish]

10. J.G. Covin, D.P. Slevin, J. Bus. Venturing, 5, pp. 123-135 (1990) 